\title{
XVIII. Notice relative to the publication of the Scientific Memoirs
}

\section{Richard Taylor}

To cite this article: Richard Taylor (1837) XVIII. Notice relative to the publication of the Scientific Memoirs, Philosophical Magazine Series 3, 10:59, 81-84, DOI: 10.1080/14786443708649084

To link to this article: http://dx.doi.org/10.1080/14786443708649084

曲 Published online: 01 Jun 2009.

Submit your article to this journal $\asymp$

Џ Article views: 2

Q View related articles $\sqsubset$ 


\title{
LOND'ON AND EDINBURGH
}

\section{PHILOSOPHICAL MAGAZINE}

\author{
A N D \\ JOURNAI OF SCIENCE.
}

[THIRD SERIES.]

FEB RUARY 1837.

\section{Notice relative to the Publication of the Scientific Memoirs. By Richard Taylor.}

T AVAIL myself of the opportunity which the Philosophical 1 Magazine affords me, to announce the publication of the Third Part of the subsidiary work in which I have lately engaged, the Scientific Memorrs, and to appeal for support and assistance to all those who may be satisfied of the utility and necessity of such an instrument for furthering the progress of scientific pursuits in this country, by giving readier access to the labours of foreign philosophers.

The views with which the work was undertaken were thus stated in the Advertisement prefixed to the First Part :

"In order to bespeak the favour of the public to this new undertaking, I shall merely state that the want of such a work has been suggested to me, during a long connexion with journals of science, by my experience of the difficulty of giving to the English reader, within the necessary limits of those works, a sufficiert view of the state and progress of the sciences in other countries. Short abstracts are given, and now and then entire translations of important memoirs; but original communications, and the scientific proceedings of our own country, now occupy so great a space in our journals as to make it impossible to do justice to the researches of foreigners. Many, indeed, are the valuable memoirs in which these are recorded, which have furnished subjects for investigation and discussion among the most distinguished of our countrymen, but which in their entire form have never appeared in English, and can be referred to only in a small number of public libraries.

"Projects for supplying this deficiency have been entertained at various times both by societies and individuals : the scientific journals, also, which have successively existed have been looked to with this view. But experience seems to have proved that a regular and full supply of such matter is not consistent with their plan or limits; and a considerable increase of their bulk and cost might reduce the number of purchasers, and

Third Series. Vol. 10. No. 59. Feb.1837. M 
lessen the support which in this country is already scarcely sufficient to keep them in existence. I have thought it better therefore to try the experiment of a separate work devoted entirely to the publication of the more important memoirs and communications, translated from foreign transactions and journals, to appear at intervals sufficiently distant to avoid the disadvantage of haste in the execution, and yet frequent enough to keep pace with the progress of discovery and the wants of the student.

"My present intention is, that the quarterly parts should form an annual volume, which may possess a permanent value, as a depository of those memoirs in which philosophers of other countries have fully developed and carefully recorded their views and their discoveries. With regard to the class or arrangement of subjects, I have thought it best not to confine myself at the outset within any fixed plan of selection; but to endeavour from time to time, with the advice and assistance of men of science in our own country, to make it subsidiary to their pursuits, and illustrative of the objects of inquiry which most engage their attention.

"I have been greatly encouraged by the opinions which have been expressed to me as to the probable usefulness of a work of this kind, as well as by the valuable suggestions and assistance with which I have been favoured; and, should the patronage of the public be sufficient to enable me to persevere, I may have the satisfaction of making my occupations conducive to the interests of science."

How far the execution of the design may have hitherto been generally satisfactory $I$ know not. The approbation and patronage of many distinguished persons of the highest scientific eminence greatly encourage me to persevere; but, as yet, the number of purchasers has not been nearly sufficient to defray the cost of publication. I do not hesitate, therefore, to make an appeal to all who may participate in the wish for the continuance of the work, trusting that they will lend their active aid in promoting its success. With a demand sufficient to cover the expenses, I should determine to proceed, being more than ever convinced of the need of such a work, and having made various arrangements for its improvement.

The following are the Memoirs contained in the First and Second Part :

M. Melloni, On the Free Transmission of Radiant Heat through different Solid and Liquid Bodies;

New Researches relative to the Immediate Transmission of Radiant Heat through different Solid and Liquid Bodies; and,

Memoir on the Polarization of Heat. (From the Annales de Chimie et de Physique.)

Prof. H.W.Duve, Experiments on the Circular Polarization of Light; and, Description of an Apparatus for exhibiting the Phænomena of the Rectilinear, Elliptic and Circular Polarization of Light. (From Poggendorff's Annalen der Pluysik und Chemie.)

M. Noвгі., A Memoir on Colours in general, and particularly on a new Chromatic Scale deduced from Metallochromy for Scientific and Practical Purposes. (From the Bibliothèque Universelle des Sciences, \&c.)

M. Poisson, On the Mathematical Theory of Heat. (From the Annales de Chimie et de Physique.)

M. SAvarT, Researches on the Elasticity of Bodies which crystallize regularly. (From the Annales de Chimic et de Physique.) 
Prof. LöwrG, Experiments on the Essential Oil of the Spiraa Ulmaria, or Meadow Sweet. (From Poggendorff's Annalen.)

Baron Walckena En, Researches relative to the Insects known to the Ancients and Moderns by which the Vine is infested, and on the Means of preventing their Ravages. (From the Annales de la Société Entomologique de France.)

Dr. Carus, The Kingdoms of Nature, their Life and Affinity. (From the Zeitschrift für Natur und Heilkunde.)

J. A. Balard, Researches concerning the Nature of the Bleaching Compounds of Chlorine. (From the Annales de Chimie et de Physique.)

E. Lenz, On the Laws of the Conducting Powers of Wires of different Lengths and Diameters for Electricity. (From the Memoirs of the Acadeny of Sciences of St. Petersburg.)

Among these it will be seen that the entire series of Melloni's important investigations are now first given to the English public. In order to render the work useful and interesting, I have been alvised to give a preference to subjects which engage immediate attention in this country. Of this kind are the labours of M. Becquerel upon the artificial production of crystallized minerals by means of voltaic action. The communications of Mr. Fox and Mr. Crosse at the late meeting of the British Association at Bristol have excited much interest upon this subject, at the time and subsequently. (See pp. 228 and 537 of our preceding volume.) What had been done by Becquerel with regard to it appears, however, to have been unknown both to those gentlemen and a great part of their auditors, the only accounts of his experiments that had appeared in this country being our short notice in 1830, (Philosophical Magazine and Annals, vol. xii. p. 226,) and that in Mr. Whewell's Report on Mineralogy. In preparing for publication M. Becquerel's paper I have been favoured with the valuable assistance of Mr. Brooke and Mr. Golding Bird: and for the highly important Memoir by Mossotti I am indebted to Prof. Faraday, who kindly communicated to me a copy which he had just received from the author. These occupy a portion of the Third Part; together with the two entire Memoirs of Ehrenberg on his discoveries of Fossil Infusoria, which are just now engaging much of the attention of naturalists. Two additional papers by Melloni are now given, in one of which he describes his mode of separating the rays of light from those of heat. The insertion of Von Wrede's Memoir on the absorption of light was oblig.. ingly suggested to me by Professor Powell.

List of the Memoirs contained in Part III., just published :

M. Clapeyron, On the Motive Power of Heat. (From the Journal de l'Ecule Royale Polytechnique.)

Dr. Burmeister, On the Sound produced by Insects in Flying. (From Poggendorff's Annalen.)

M. Mellont, On the Refiection of Radiant Heat; and,

On the Theory of the Identity of the Agents which produce Light and

Radiant Heat. (From the Annales de Chimie et de Physique.) 
M. Brot, On the Constitution of the higher Regions of the Earth's Atmosphere. (From the Comptes Rendus des Séances de l'Acad'́mie des Sciences.)

Prof. Ehrenberg, On Fossil Infusoria.-The two Memoirs entire, with an Engraving of the Figures. (From Poggendorf's Annalen.)

M. Becqueres, On the artificial production of Crystallized Minerals by Voltaic action.

Prof. H. Rose, On a New Combination of Anhydrous Sulphuric and Sulphurous Acids. (From Poggendorff's Annalen.)

M. Mossotrr, On the Forces which regulate the Internal Constitution of Bodies. (A Memoir published separately; containing the views respecting the identity of origin of gravitation, the attraction of aggregation, and electrical attraction, involving the discovery of the physical cause of gravitation, which were explained, from this Memoir, by Mr. Faraday at the first evening meeting of the Royal Institution for the present season, January 20,1837 .)

M. Pelouze, On certain Combinations of a new Acid, formed of Azote, Sulphur, and Oxygen. (From the Annales de Chimie et de Physique.)

Baror von Wrede, On the Absorption of Light, according to the Theory of Undulations. (From Poggendorf's Annalen.)

My comnexions and my profession may afford me, perhaps, advantages for carrying on the work with a less amount of support than would be requisite if it were in other hands. I cannot, however, be expected to incur a considerable loss; and I look with confidence to those who approve my attempt to give me their active aid. If they wish the work to be continued, they will, I trust, exert themselves to increase the number of purchasers, which at present is far below what is absolutely necessary.

I have only to add, that the attention requisite for conducting this work I shall be happy to give, if its circulation can be so far extended as barely to pay the cost; and, though necessarily it can hardly be of a popular character, this is not a greater degree of success than may be hoped for, in this country and its dependencies.

Richard TAYLOR.

XIX. Experimental Researches on the Nature and Properties of Albumen, \&c. By Golding Bun, Esq., F.L.S., F.G.S., Lecturer on Experimental Philosophy at Guy's Hospital.

[Continued from vol. ix. p. 115, and concluded.]

$\mathrm{N}$ the former part of this communication I pointed out the solubility of albumen after its coagulation by alcohol, \&c., in water saturated with carbonic acid, as well as the curious fact of that acid decomposing the.alkaline albuminates, causing the separation and consequent precipitation of the albumen in an insoluble form, capable of being redissolved by an excess of the acid. I also mentioned some circumstances connected with the action of coagulated albumen on the carbonates of 